\title{
THE EFFECTS OF DIETARY COPPER SUPPLEMENTATION ON OXIDATIVE AND ANTIOXIDANT SYSTEMS INBROILER CHICKENS
}

\author{
EFECTOS DE LA SUPLEMENTACIÓN CON COBRE SOBRE LOS SISTEMAS OXIDATIVO \\ YANTIOXIDANTE EN BROILERS
}

\author{
Ajuwon, O.R. ${ }^{*}$, Idowu, O.M.O. ${ }^{3}$, Afolabi, S.A. ${ }^{2}$, Kehinde, B.O. ${ }^{2}$, Oguntola, O.O. ${ }^{2}$ \\ and Olatunbosun, K.O. ${ }^{2}$
}

\begin{abstract}
${ }^{1}$ Oxidative Stress Research Centre. Faculty of Health and Wellness Sciences. Cape Peninsula University of Technology. Bellville. South Africa. *waleajuwon26@yahoo.co.uk

${ }^{2}$ Department of Environmental Management and Toxicology. University of Agriculture. Abeokuta. Nigeria. ${ }^{3}$ Department of Animal Nutrition. University of Agriculture. Abeokuta. Nigeria.
\end{abstract}

\section{AdDitionAL KEYWORDS}

Oxidative damage. Erythrocytes. Liver. Blood.

\section{SUMMARY}

This study was designed to investigate the in vivo effects of dietary copper supplementation on the oxidative and antioxidant systems in the erythrocyte and liver of broiler chickens. Birds were exposed to commercially prepared diet (control group, $n=20$ ) or commercial diet supplemented with $250 \mathrm{mg} \mathrm{CuSO}_{4} / \mathrm{kg}$ diet (experimental group, $\mathrm{n}=$ 20) for 6 weeks. The copper burdens, oxidative lipid peroxidation (LPO), glutathione (GSH) concentration, activity of antioxidant enzymes, superoxide dismutase (SOD) and catalase (CAT) were evaluated in the erythrocyte and hepatic tissues using well established techniques. Oral exposure to copper for a period of 6 weeks significantly $(p<0.05)$ increased the copper burden and lipid peroxidation respectively in the blood and liver of treated birds compared with control. Concomitantly, there was a significant reduction $(p<0.05)$ in the activities of SOD, CAT, and the concentration of GSH in the exposed birds compared with control. It is concluded from this study that dietary copper supplementation (250 $\mathrm{mg} \mathrm{CuSO}_{4} / \mathrm{kg}$ diet) induced oxidative stress in the erythrocyte and liver of broiler chickens.

\section{RESUMEN}

El estudio fue diseñado para estudiar los efectos in vivo de la suplementación dietética con cobre sobre los sistemas oxidativos y antioxidantes

Recibido: 27-1-09. Aceptado: 15-9-09.

\author{
Palabras clave adicionales \\ Daños oxidativos. Eritrocitos. Hígado. Sangre.
}

de los eritrocitos y el hígado de broilers. Las aves fueron sometidas a una dieta comercial (grupo control, $\mathrm{n}=20$ ) o suplementada con $250 \mathrm{mg} \mathrm{CuSO}_{4} /$ $\mathrm{kg}$ dieta (grupo experimental, $\mathrm{n}=20$ ) durante 6 semanas. En los eritrocitos y tejido hepático, se evaluó, empleando técnicas consolidadas, la sobrecarga de cobre, la peroxidación oxidativa de los lípidos (LPO), concentración de glutatión (GSH), actividad de los enzimas antioxidantes, super oxido dismutasa (SOD) y catalasa (CAT). La exposición oral al cobre, durante 6 semanas, aumentó $(p<0,05)$ la carga de cobre y la peroxidación lipídica respectivamente en sangre e hígado de las aves tratadas respecto del control. Se concluye, que la suplementación dietética con cobre (250 $\mathrm{mg} \mathrm{CuSO}_{4} / \mathrm{kg}$ dieta) indujo estrés oxidativo en los eritrocitos e hígado de los broilers.

\section{INTRODUCTION}

Copper is present in all tissues and is a functional constituent of all living cells. Because of its significance in most of the enzymatic reactions and cellular metabolism, $\mathrm{Cu}$ is an essential component of human nutrition and the diets of birds, including poultry.

Commercial organic copper sources and reagent-grade inorganic copper salts have 


\section{AJUWON, IDOWU, AFOLABI, KEHINDE, OGUNTOLA AND OLATUNBOSUN}

been used for the supplementation of animal feeds (Guo et al., 2001). Copper is routinely supplemented to swine and poultry diets at concentrations above requirement of the animals, because pharmacological concentrations of copper act as a growth stimulant in these species, thereby improving growth performance, including increase in body weight gain and feed intake (Cromwell et al., 1989; Bakalli et al., 1995). Lien et al. (2004), found supplemental copper to reduce VLDLcholesterol and enhance HDL-cholesterol in egg yolk of laying hens. Also $\mathrm{CuSO}_{4}$ supplementation has been reported to reduce the saturated fatty acid proportion in abdominal fat and increase PUFA:SFA ratio, as well as reduces the cholesterol content in meat of broiler chickens (Skrivan et al., 2000, Xia et al., 2004). Research evidences have shown that copper regulates cholesterol biosynthesis by reducing hepatic glutathione concentration (Kim et al., 1992). A large decrease in the reducing capacity of the cellular redox couples, such as glutathione has been used as an indication of oxidative stress in rats and other animal models (Schafer and Buettner, 2001).

Although copper is a major essential element, serious toxic effects of this metal has been reported when it is over loaded (Toplan et al., 2005, Zhang et al., 2000, Bremner, 1998). Copper ions are powerful catalysts of free radical damage. Its ability to induce oxidative damage is generally attributed to the formation of highly reactive hydroxyl radical $\left(\mathrm{OH}^{-}\right)$from hydrogen peroxide $\left(\mathrm{H}_{2} \mathrm{O}_{2}\right)$ via the Haber-Weiss reaction (Bremner, 1998; Kadiiska et al., 1993). The $\mathrm{OH}^{-}$radical generated during copper-induced oxidative stress may lead to lipid peroxidation and formation of reactive products which may be involved in severe damage of cell molecules and structures (Videla et al., 2003). Lipid peroxidation as evidenced by increased malondialdehyde content, as well as alteration in membrane integrity and fatty acid composition have been observed in the erythrocytes and hepatocytes of copper exposed animals (Zhang et al., 2000) and erythrocytes of human (Hochstein et al.,1980). Erythrocytes are particularly sensitive to oxidative stress and like other cells of aerobic organisms, they are supplied with protective antioxidant mechanisms in order to counteract the toxic action of oxygen radicals. Defense is provided by enzyme activities like superoxide dismutase, catalase and glutathione peroxidase. Superoxide dismutase is the enzyme that catalyses the dismutation of the highly reactive superoxide anion to molecular oxygen $\left(\mathrm{O}_{2}\right)$ and to the less reactive species, hydrogen peroxide $\left(\mathrm{H}_{2} \mathrm{O}_{2}\right)$. Glutathione (GSH), GSH peroxidase and catalase, under most circumstances eliminate the resulting $\mathrm{H}_{2} \mathrm{O}_{2}$ (Fridovich, 1995, Teixeira et al., 1998).

Although reports of studies on the use of copper as a feed supplement in poultry has been widely published, however to the best of our knowledge, information regarding the toxicity of copper in broiler chickens is still limited. Therefore, prompted by this paucity of data, we evaluated the copper burden, status of lipid peroxidation and antioxidant systems in the erythrocyte and liver of broiler chickens whose diet has been supplemented with copper.

\section{MATERIALS AND METHODS}

\section{ANIMALS AND EXPERIMENTAL DESIGN}

This study protocol was approved by the University of Agriculture, Abeokuta (Nigeria), animal use and welfare committee and all investigation adhered strictly to the statement for the use of animals in research.

Forty unsexed, three-week old broiler chickens (Anak 2000) were purchased from the UNAAB-LEVENTIS Agro-Allied Industry, Abeokuta, Nigeria. The birds were kept in standard battery cages with automatic nipple drinkers and standard feeding trough. Feeds and water were given ad libitum. The birds were divided into two groups of twenty 


\section{DIETARY COPPER AND OXIDATIVE AND ANTIOXIDANT SYSTEMS IN BROILERS}

birds each. Group 1 served as the control and was fed on a basal diet purchased from UNAAB-LEVENTIS Agro-Allied Industry. Group 2, the treatment group, were fed on the same basal diet supplemented with 250 $\mathrm{mg} \mathrm{CuSO}_{4} / \mathrm{kg}$ diet. This feeding protocol continued for a total of 42 days. The basal diet was formulated following the procedure of Idowu et al. (2003), and its composition is shown in table $\mathbf{I}$.

\section{SAMPLEPREPARATION}

At the end of the feeding period, birds in the two groups were starved overnight for 12 hours. Exactly $10 \mathrm{ml}$ of blood was drawn from the brachial vein of each bird into heparinized tubes and $2 \mathrm{ml}$ aliquot of blood sample was transferred into another set of tubes for copper content determination. The remaining blood was centrifuged at $750 \mathrm{xg}$ for 5 minutes, supernatants discarded and

Table I. Composition of the basal diet. (Composición de la dieta basal).

\begin{tabular}{lc}
\hline Ingredients & \\
Maize \% & 44.00 \\
Soya bean full fat \% & 36.00 \\
Rice husk \% & 12.33 \\
Palm oil \% & 4.00 \\
Bone meal \% & 2.50 \\
Oyster shell \% & 0.50 \\
Vitamin/mineral premix \% & 0.25 \\
Salt (NaCl) \% & 0.25 \\
Methionine \% & 0.17 \\
& \\
Determined analysis & \\
Crude protein \% & 19.90 \\
Fat \% & 11.00 \\
Ash \% & 14.31 \\
Fibre \% & 4.78 \\
& \\
Calculated analysis & \\
Energy (ME) kcal/kg & 3203.76 \\
Energy/protein ratio & 160.20 \\
Methionine \% & 0.45 \\
Calcium \% & 1.33 \\
Phosphorus \% & 0.69 \\
Copper mg/kg & 5.90 \\
\hline
\end{tabular}

the erythrocytes washed thrice using $0.9 \%$ $\mathrm{NaCl}$ for lipid peroxidation, catalase, glutathione and superoxide dismutase activity determination. The birds were sacrificed and liver excised, perfused with ice-cold $0.9 \% \mathrm{NaCl}$ solution to remove residual blood. Half of the liver was homogenized in ice-cold $50 \mathrm{mM}$ sodium phosphate buffer and $0.1 \mathrm{mM} \mathrm{Na}_{2}$ EDTA ( $\left.\mathrm{pH} 7.8\right)$. The soluble fraction was prepared by centrifugation at $1000 \mathrm{x}$ g for 20 minutes. The remaining half was stored frozen for copper content determination.

\section{COPPER CONTENTDETERMINATION}

Exactly $1 \mathrm{ml}$ of blood was digested with $10 \mathrm{ml}$ concentrated nitric acid and digests brought to $25 \mathrm{ml}$ with deionised water (Ademuyiwa, 1995). For liver, $1 \mathrm{~g}$ was dried to a constant weight at $85^{\circ} \mathrm{C}$. Dried samples were cold digested in $2 \mathrm{ml}$ of nitric acid overnight. They were then hot digested on a block digester at $120^{\circ} \mathrm{C}$ until all the organic matter was dissolved. Two milliliters of $30 \%$ $(\mathrm{w} / \mathrm{v})$ hydrogen peroxide were added during digestion to enhance oxidization. The digests were allowed to cool, and then diluted to $25 \mathrm{ml}$ with deionised water (Alonso et al., 2000). Copper concentrations in the digests were determined by atomic absorption spectrometry (Buck Scientific, Model 210, Connecticut, USA). Values were expressed as $\mu \mathrm{g} / \mathrm{ml}$ of blood or $\mu \mathrm{g} / \mathrm{g}$ of tissue.

\section{MEASUREMENT OF INDICES OF OXIDATIVE STRESS}

Lipid peroxidation: The extent of lipid peroxidation was estimated in terms of thiobarbituric acid reactive substances (TBARS), using malondialdehyde (MDA) as standard by method of Beuge and Aust (1978). Briefly, $1 \mathrm{ml}$ of erythrocyte or liver homogenate was added with $2 \mathrm{ml}$ of the TCA-TBA-HCl reagent $[15 \%(\mathrm{w} / \mathrm{v}) \mathrm{TCA}$, $0.375 \%(\mathrm{w} / \mathrm{v}) \mathrm{TBA}$ and $0.25 \mathrm{~N} \mathrm{HCl}]$. The contents were boiled for 15 minutes, cooled and centrifuged at $1000 \times \mathrm{g}$ to remove the 


\section{AJUWON, IDOWU, AFOLABI, KEHINDE, OGUNTOLA AND OLATUNBOSUN}

precipitate. The absorbance was read at 535 $\mathrm{nm}$ and the MDA concentration of the sample calculated using extinction coefficient of $1.56 \times 10^{5} \mathrm{M}^{-1} \mathrm{Cm}^{-1}$ and expressed as $\mu \mathrm{mol}$ MDA/g Hb for erythrocyte and $\mu$ mol MDA/ $\mathrm{g}$ tissue for liver.

Catalase determination was carried out following the method described by Clairborne (1986), in which the disappearance of $\mathrm{H}_{2} \mathrm{O}_{2}$ was monitored spectrophotometrically at $240 \mathrm{~nm}$. Briefly, $20 \mu \mathrm{l}$ of erythrocyte or liver homogenate was added to $1 \mathrm{ml}$ of $0.05 \mathrm{M}$ phosphate buffer $\mathrm{pH} 7.0$. Then, $0.5 \mathrm{ml}$ of $30 \% \mathrm{H}_{2} \mathrm{O}_{2}$ was added to the buffered sample to initiate the reaction. The change in absorbance for 1 minute at 10 seconds interval was recorded. One unit activity is defined as the amount of enzyme catalyzing the formation of water and oxygen from hydrogen peroxide under assay condition.

Superoxide dismutase was assayed according to a modified procedure of Das et al. (2000). In this method, $1.4 \mathrm{ml}$ aliquot of the reaction mixture (comprising $1.11 \mathrm{ml}$ of $50 \mathrm{mM}$ phosphate buffer, $\mathrm{pH} 7.4,0.075 \mathrm{ml}$ of $20 \mathrm{mM}$ L-Methionine, $0.04 \mathrm{ml}$ of $1 \%(\mathrm{v} / \mathrm{v})$ Triton X-100, $0.075 \mathrm{ml}$ of $10 \mathrm{mM}$ hydroxylamine hydrochloride and $0.1 \mathrm{ml}$ of $50 \mathrm{mM}$ EDTA) was added to $100 \mu 1$ of the erythrocyte or liver homogenate and incubated at $30^{\circ} \mathrm{C}$ for 5 minutes. $80 \mu \mathrm{l}$ of riboflavin was then added and the tubes were exposed to 20W-Philips fluorescent lamps for 10 minutes. After the exposure time, $1 \mathrm{ml}$ of Greiss reagent (mixture of equal volume of $1 \%$ sulphanilamide in 5\% phosphoric acid) was added and absorbance of the colour formed measured at $543 \mathrm{~nm}$. One unit of enzyme activity was measured as the amount of SOD capable of inhibiting $50 \%$ of nitrite formation under assay condition.

Glutathione concentration was determined in samples according to the method of Boyne and Ellman (1972). Briefly, $1 \mathrm{ml}$ of erythrocyte or liver homogenate was treated with $4.0 \mathrm{ml}$ of metaphosphoric acid precipitating solution (1.67 g of glacial metaphosphoric acid, $0.2 \mathrm{~g}$ EDTA and $30 \mathrm{~g} \mathrm{NaCl}$ dissolved in $100 \mathrm{ml}$ of distilled water). After centrifugation, $2 \mathrm{ml}$ of the supernatant was mixed with $0.2 \mathrm{ml}$ of $0.4 \mathrm{M} \mathrm{Na}_{2} \mathrm{HPO}_{4}$ and $1 \mathrm{ml}$ of DTNB (5, 5' -Dithio-bis-(2-nitrobenzoic acid) reagent $(40 \mathrm{mg}$ DTNB in $100 \mathrm{ml}$ of aqueous $1 \%$ trisodium citrate). Absorbance was read at $412 \mathrm{~nm}$ within 2 minutes. GSH concentration was expressed as $\mathrm{mmol} / \mathrm{g} \mathrm{Hb}$ or $\mathrm{mmol} / \mathrm{g}$ tissue.

Protein content was determined according to the method of Bradford (1976) using bovine serum albumin as standard. All chemical used in the enzymatic activity determination were of analytical purity and were obtained from Sigma Chemical.

\section{StATISTICAL ANALYSIS}

The results of all measurements were expressed as mean \pm standard deviation. Data collected were subjected to analysis of variance (ANOVA) and means separated using student's t-test with a probability factor of $\mathrm{p}<0.05$ considered significant.

\section{RESULTS}

\section{BIOCHEMICAL FINDINGS}

Copper burden, lipid peroxidation, SOD, CAT and GSH levels in the erythrocyte and liver for each group are presented in tables II and III respectively. Copper supplementation in the diet significantly $(\mathrm{p}<0.05)$ increased the copper burden in the blood and liver of treated birds compared with control. The mean copper concentration in the blood and liver of treated group were respectively 2.15 and 1.67 times higher than the control. A significant elevation $(\mathrm{p}<0.05)$ was noted in lipid peroxidation in the copper exposed group with values being 3.67 and 1.25 times higher than control in both erythrocyte and liver respectively.

Values of SOD activity showed a significant reduction $(\mathrm{p}<0.05)$ in the erythrocyte $(10.9 \pm 1.09$ vs. $18.3 \pm 1.21)$ and liver (49.8 $\pm 14.94 v s .77 .4 \pm 13.60)$ of copper exposed birds compared to the control. Similarly, a significant decrease was noted 
Table II. Blood copper burden, erythrocyte lipid peroxidation, SOD, CAT, and GSH concentrations. (Carga de cobre, peroxidación lipídica en los eritrocitos y concentraciones de SOD, CAT y GSH en la sangre).

\begin{tabular}{lcr}
\hline Parameter & $\begin{array}{c}\text { Control } \\
(\mathrm{n}=20)\end{array}$ & \multicolumn{1}{c}{$\begin{array}{c}\text { Treatment } \\
(\mathrm{n}=20)\end{array}$} \\
\hline Copper burden $^{1}$ & $2.0 \pm 0.73^{\mathrm{b}}$ & $4.3 \pm 0.28^{\mathrm{a}}$ \\
Lipid peroxidation $^{2}$ & $0.3 \pm 0.07^{\mathrm{b}}$ & $1.1 \pm 0.19^{\mathrm{a}}$ \\
SOD & $18.3 \pm 1.21^{\mathrm{a}}$ & $10.9 \pm 1.09^{\mathrm{b}}$ \\
CAT & $3.8 \pm 0.65^{\mathrm{a}}$ & $1.8 \pm 0.35^{\mathrm{b}}$ \\
GSH & $0.9 \pm 0.17^{\mathrm{a}}$ & $0.3 \pm 0.19^{\mathrm{b}}$ \\
\hline
\end{tabular}

Values in the same row with different superscript are significantly different at $p<0.05$.

${ }^{1} \mu \mathrm{g} / \mathrm{ml} ;{ }^{2} \mu \mathrm{mol} \mathrm{MDA} / \mathrm{g} \mathrm{Hb}(\mathrm{MDA}=$ malondialdehyde); SOD: superoxide dismutase (unit/mg protein);CAT: catalase (unit/mg protein); GSH: glutathione (mmol/ $\mathrm{g} \mathrm{Hb})$.

in catalase activity after copper exposure in both the erythrocyte and liver (tables II and III). The level of glutathione indicated a significant depletion $(\mathrm{p}<0.05)$ in both erythrocyte $(67 \%$ lower) and liver $(36 \%$ lower) of birds exposed to copper compared to those of the control.

\section{DISCUSSION}

Numerous studies have reported toxic effects induced when animals and humans are exposed to certain metals (Valko et al., 2005, Stohs and Bagchi, 1995). Several mechanisms have been proposed to explain copper-induced cellular toxicity. Most often the basis for these theories is the ability of free $\mathrm{Cu}$ ions to participate in the formation of reactive oxygen species (ROS) and other free radicals (Gaetke and Chow, 2003). The most important consequences of free radical production are lipid peroxidation increase and change in permeability of cell membrane. The significant increase in lipid peroxidation in the experimental group observed in this study could be explained by damage due to
Table III. Liver copper burden, lipid peroxidation, SOD, CAT and GSH concentrations. (Carga de cobre, peroxidación lipídica en los eritrocitos y concentraciones de SOD, CAT y GSH en el hígado).

\begin{tabular}{lcc}
\hline Parameter & $\begin{array}{c}\text { Control } \\
(\mathrm{n}=20)\end{array}$ & $\begin{array}{c}\text { Treatment } \\
(\mathrm{n}=20)\end{array}$ \\
\hline Copper burden $^{1}$ & $5.1 \pm 0.61^{\mathrm{b}}$ & $8.5 \pm 0.66^{\mathrm{a}}$ \\
Lipid peroxidation $^{2}$ & $0.4 \pm 0.02^{\mathrm{b}}$ & $0.5 \pm 0.08^{\mathrm{a}}$ \\
SOD & $77.4 \pm 13.60^{\mathrm{a}}$ & $49.8 \pm 14.94^{\mathrm{b}}$ \\
CAT & $16.0 \pm 1.26^{\mathrm{a}}$ & $9.6 \pm 2.44^{\mathrm{b}}$ \\
GSH & $3.9 \pm 0.17^{\mathrm{a}}$ & $2.5 \pm 0.43^{\mathrm{b}}$ \\
\hline
\end{tabular}

Values in the same row with different superscript are significantly different at $p<0.05$.

${ }^{1} \mu \mathrm{g} / \mathrm{g}$ tissue; ${ }^{2} \mu \mathrm{mol} \mathrm{MDA} / \mathrm{g}$ tissue (MDA= malondialdehyde); SOD: superoxide dismutase (unit/mg protein); CAT: catalase (unit/mg protein); $\mathrm{GSH}$ : glutathione (mmol/g tissue).

oxidative stress in tissue. Copper produce $\mathrm{OH}^{-}$radical from $\mathrm{H}_{2} \mathrm{O}_{2}$ and this is capable of reacting with practically every biological molecule, initiating oxidative damage by abstracting the hydrogen from an amino bearing carbon to form a carbon centered protein radical and from an unsaturated fatty acid to form a lipid radical (Powell, 2000). Studies by Toplan et al. (2005) and Zhang et al. (2000) also corroborated our present findings.

Lipid peroxidation is a free radicalmediated chain reaction, since it is self perpetuating. The length of the propagation depends upon chain breaking antioxidants, such as the enzymes SOD, catalase and glutathione peroxidase (Diniz et al., 2003). In this study, supplementation of $\mathrm{CuSO}_{4}$ $(250 \mathrm{mg} / \mathrm{kg}$ diet $)$ in the diet of broilers resulted in a reduction in the activities of SOD and catalase compared with birds in the control group. The results of research on copper influence on SOD activity are divergent. Previous studies by Toplan et al. (2005), in which rats were given $250 \mathrm{mg} / \mathrm{l}$ copper for 9 weeks and Zhang et al. (2000) 
when rats were overloaded with $500 \mathrm{mg} \mathrm{Cu} /$ $\mathrm{kg} / \mathrm{bw}$ for eight weeks showed that SOD activity was significantly reduced, as also observed in this study. However Ozcelik et al. (2003), administered water containing $100 \mu \mathrm{g} / \mathrm{ml}$ copper for 4 weeks to rats and observed an increase in the activity of SOD in experimental animals compared to those of the control. Sansinanea et al. (1998), in a study to explain the cytotoxicity of excessive free radical production in the liver of rats, gave water containing $0.2 \%$ solution of $\mathrm{CuSO}_{4}$ and observed SOD activity to be higher in experimental group animals than that of control group animals. SOD catalyses the dismutation of superoxide radical leading to formation of hydrogen peroxide which in turn is detoxified by the enzyme catalase (Fridovich, 1995). Therefore, the decreased SOD and CAT activity observed in this study may be due to the depletion or inactivation of the enzymes by production of free radicals (Kono and Fridovich, 1982) such as superoxide and $\mathrm{H}_{2} \mathrm{O}_{2}$ which in turn generate hydroxyl radical resulting in initiation and propagation of lipid peroxidation.

One of the mechanisms by which heavy metals produce effect is through their interaction with cellular sulphydryl groups in proteins. Sulphydryl groups thus serves as a source of electrons for reduction and also mediate the methylation process. When the availability of free thiol group is low, enhanced expression of toxicity in the form of oxidative stress could occur. Since most metals have high affinity for the sulphydryl (SH) groups, endogenous $\mathrm{SH}$ compounds such as metallothionein (MT) and GSH are known to be involved in metal toxicity. GSH performs a pivotal role in maintaining the metabolic and transport function of cells. It may function as an intracellular chelater and a metal detoxifying agent. The importance of GSH in metal detoxification is also supported by its role in removal of toxic oxygen species (Ishikawa and Sies, 1989; Seidegard and Ekstrom, 1997). In this study, GSH levels were lower in the copper treated group compared with the control group. The reduction in the GSH levels observed in this study might be due to the reaction of GSH with copper or with free radicals promoted by copper supplementation (Ishikawa and Sies, 1989; Deleve and Kaplowitz, 1991). Also an impairment of GSH synthesis or regenerating enzyme could be responsible for the observed reduction of GSH (Hultberg et al., 1997).

\section{CONCLUSION}

In conclusion, this study has demonstrated that copper intake at high concentration $\left(250 \mathrm{mg} \mathrm{CuSO}_{4} / \mathrm{kg}\right.$ diet) induced adverse effects on the oxidative and antioxidant systems in broiler chickens as shown by the increase in lipid peroxidation and reduction in the activities of SOD and catalase, as well as the concentration of glutathione in both the erythrocyte and the liver. This in turn may be detrimental to the health of the birds since oxidative stress can lead to increased prevalence of infectious diseases via impairment of immune cell functions. Nevertheless, the beneficial effects of $\mathrm{Cu}$ supplementation in poultry may be utilized by reducing the copper supplementation level in the diet. Furthermore, dose-response relationship experiments are suggested in order to determine a threshold dose below which there would be no toxicity.

\section{ACKNOWLEDGEMENTS}

The authors are grateful to Mrs. O. Sorinola for her technical assistance. We are also indebted to Professors O. Ademuyiwa and T.A. Arowolo for going through the manuscript, and also to Dr. O.M. Sogunle for helping out with the statistical analysis. 


\section{DIETARY COPPER AND OXIDATIVE AND ANTIOXIDANT SYSTEMS IN BROILERS}

\section{REFERENCES}

Ademuyiwa, O. 1995. Zur toxikologie der arsenkupfer wechsekwirlung im saugetierorgani mimus. Untersuchunge an ratten. Ph.D. Thesis. University of Munich. Munich. Federal Republic of Germany.

Alonso, M.L., Benedito, J.L., Miranda, M., Castillo, C., Hernandez, J. and Shore, R.F. 2000. Arsenic, cadmium, lead, copper and zinc in cattle from Galicia, NW Spain. Sci. Total Environ., 246: 237248.

Bakalli, R.I., Pesti, G.M., Ragland, W.L. and Konjufca, V. 1995. Dietary copper in excess of nutritional requirement reduces plasma, and breast muscle cholesterol of chickens. Poultry Sci., 74: 360365.

Beuge, J.A. and Aust, S.D. 1978. Microsomal lipid peroxidation. Methods Enzymol., 52: 302-305.

Boyne, A.F. and Ellman, G.L. 1972. A methodology for analysis of tissue sulphydryl components. Anal. Biochem., 46: 639-653.

Bradford, M.M. 1976. A rapid and sensitive method for the quantification of microgram quantities of protein utilizing the principle of protein-dye binding. Anal. Biochem., 46: 639-653.

Bremner, I. 1998. Manifestations of copper excess. Am. J. Clin. Nutr., 67: 1069S-1073S.

Clairborne, A. 1986. Catalase activity. In: CRC Handbook of methods for oxygen radical research. Greenwald RA (ed). CRC Press Inc. Boca Raton, FL. pp. 283-284.

Cromwell, G.L., Stahly, T.S. and Monegue, H.J. 1989. Effects of source and level of copper on performance and liver copper stores in weanling pigs. J. Anim. Sci., 67: 2996-3002.

Das, K., Samanta, L. and Chainy, G.B.N. 2000. A modified spectrophotometric assay of superoxide dismutase using nitrite formation by superoxide radicals. Ind. J. Biochem. Biophys., 37: 201-204.

Deleve, L.D. and Kaplowitz, N. 1991. Glutathione metabolism and its role in hepatotoxicity. Pharm. Ther., 52: 287-305.

Diniz, Y.S., Cicogna, A.C., Padovani, C.R., Silva, M.D.P., Faine, C.M., Galhardi, C.M., Rodrigues, H.G. and Novelli, E.L.B. 2003. Dietary restriction of fibre supplementation: oxidative stress and metabolic shifting for cardiac health. Can. J. Physiol. Pharmacol., 81: 1042-1048.
Fridovich, I. 1995. Superoxide radical and superoxide dismutases. Annu. Rev. Biochem., 64: 97-112.

Gaetke, L.M. and Chow, C.K. 2003. Copper toxicity, oxidative stress, and antioxidant nutrients. Toxicology, 189: 147-163.

Guo, R., Henry, P.R., Holwerda, R.A., Cao, J., Littelli, R.C., Miles, R.D. and Ammerman, C.B. 2001. Chemical characteristics and relative bioavailability of supplemental organic copper sources for poultry. J. Anim. Sci., 79: 11321141.

Hochstein, P., Kumar, K.S. and Forman, S.J. 1980. Lipid peroxidation and the cytotoxicity of copper. Ann. NY. Acad. Sci., 355: 240-248.

Hultberg, B., Anderson, A. and Isaksson, A. 1997. Copper ions differ from other thiol reactive metal ions in their effects on the concentration and redox status of thiols in HeLa cell cultures. Toxicology, 117: 89-97.

Idowu, O.M.O., Eruvbetine, D., Oduguwa, O.O., Bamgbose, A.M. and Abiola, S.S. 2003. Response of finishing broiler chickens fed three energy/protein combinations at fixed E:P ratio. Nig. J. Anim. Prod., 30: 185-191.

Ishikawa, T. and Sies, H. 1989. Glutathione as an antioxidant: toxicological aspects. In: Dolphin, D., Poulson, R., Avramovic, O. (eds). Glutathione, chemical, biochemical and medical aspects. Wiley Interscience. New York. pp. 85-111.

Kadiiska, M.B., Hanna, P.M., Jordan, S.J. and Mason, R.P. 1993. Electron spin resonance evidence for free radical generation in copper treated vitamin E- and selenium- deficient rats: in vivo spin-trapping investigation. Mol. Pharmacol., 44: 222-227.

Kim, J.W., Chao, P.Y. and Allen, A. 1992. Inhibition of elevated hepatic glutathione abolishes copper deficiency cholesterolemia. FASEB J., 6: 24672471.

Kono, Y. and Fridovich, I. 1982. Superoxide radical inhibits catalase. J. Biol. Chem., 257: 57515754.

Lien, T.F., Chen, K.L., Wu, C.P. and Lu, J.J. 2004. Effects of supplemental copper and chromium on the serum and egg traits of laying hens. Brit. Poultry Sci., 45: 535-539.

Ozcelik, D., Ozaras, R., Gurel, Z., Uzun, H. and 


\section{AJUWON, IDOWU, AFOLABI, KEHINDE, OGUNTOLA AND OLATUNBOSUN}

Aydin, S. 2003. Copper-mediated oxidative stress in rat liver. Biol. Trace Elem. Res., 96: 209-215.

Powell, S.R. 2000. The antioxidant property of Zinc. J. Nutr., 130: 1447S-1454S.

Sansinanea, A.S., Cerone, S.I., Streitenberger, S.A., Garcia, C. and Auza, N. 1998. Oxidative effect of copper hepatic copper overload. Acta. Physiol. Pharmacol. Ther. Latinoam., 48: 25-31.

Schafer, F.Q. and Buettner, G.R. 2001. Redox environment of the cell as viewed through the redox state of the glutathione disulphide/ glutathione couple. Free Radical Bio. Med., 30: 1191-1212.

Seidegard, J. and Ekstrom, G. 1997. The role of human glutathione transferase and epoxide hydrolysis in the metabolism of xenobiotics. Environ. Health Persp., 105: 791-799.

Skrivan, M., Skrivanova, V., Marounek, M., Tumova, E. and Wolf, J. 2000. Influence of dietary fat source and copper supplementation on broiler performance, fatty acid profile of meat and depot fat and on cholesterol content in meat. Brit. Poultry Sci., 41: 608-614.

Stohs, S.J. and Bagchi, D. 1995. Oxidative mechanisms in the toxicity of metal-ions. Free
Radical Bio. Med., 18: 321-336.

Teixeira, H.D., Schumacher, R.I. and Meneghini, R. 1998. Lower intracellular hydrogen peroxide levels in cells over-expressing CuZn-superoxide dismutase. Proc. Natl. Acad. Sci., 95: 7872-7875.

Toplan, S., Dariyerli, N., Ozcelik, D. and Akyolcu, M.C. 2005. The effects of copper application on oxidative and antioxidant systems in rats. Trace. Elem. Electroly., 22: 178-181.

Valko, M., Morris, H. and Cronin, M.T.D. 2005. Metal toxicity and oxidative stress. Curr. Med. Chem., 12: 1161-1208.

Videla, L.A., Fernandez, V., Tapia, G. and Varela, P. 2003. Oxidative stress-mediated hepatotoxicity of iron and copper: role of Kupffer cells. Biometals, 16: 103-111.

Xia, M.S., Hu, C.H. and Xu, Z.R. 2004. Effects of copper bearing montmorillonite on growth performance, digestive enzyme activities and intestinal microflora and morphology of male broilers. Poultry Sci., 83: 1868-1875.

Zhang, S.S., Noordin, M.M., Rahman, S.O. and Haron, J. 2000. Effects of copper overload on hepatic lipid peroxidation and antioxidant defense in rats. Vet. Hum. Toxicol., 42: 261-264. 